\title{
A Child Labor Amendment is Unnecessary
}

TT was the purpose of the American people in creating our present system of government to establish an adequate, permanent, and efficient national government. Provisions for that government were made in a novel scheme which now, even more than then, makes the government of the United States unique in the world, namely, a written constitution.

"That the people have an original riglit to establish, for their future government, sucli principles as, in their opinion, shall most conduce to their own happiness, is the basis on whicl the whole American fabric has been erected. The exercise of this original riglit is a very great exertion; nor can it, nor ouglit it, to be frequently repeated. The principles, therefore, so established, are deemed fundamental: and as the authority from whicl they proceed is suprenie, and can seldom act, tliey are designed to be permanent." 1

Those who framed the written constitution contemplated it as forming the fundamental and paramount law of the nation beyond modification except by the supreme sovereign will of the people. ${ }^{2}$

"This theory is essentially attached to a written constitution, and is, consequently, to be considered, by this court, as one of the fundamental principles of our society. It is not, therefore, to be lost siglit of, in the further consideration of this subject." 3

The powers of the national government are granted "m a constitution, intended to endure for ages to come, and consequently, to be adapted to the various crises of human affairs." "Certainly no problem of greater importance can confront the American people than whether the powers of the national government shall be changed. Such changes must be either to increase the national agency of government with the consequent diminution of the present freedom of individuals or of the states, or to decrease its powers with corresponding increase of the privileges of individuals or states. ${ }^{5}$ Under

1 Marbury v. Madison (1803) 5 U.S. (1 Cranch) 137, 175.

2 See my article, Non Judicial Administration of Law, to appear in a forthcoming issue of the University of Cincinnati Law Review.

3 Marbury v. Madison, supra note 1, at 176.

4 McCullouch v. Maryland (1819) 17 U. S. (4 Wheat.) 316, 415.

5 Cf. Dodd, Adjustment of the Constitution to New Needs (1936) 22 A.B.A.J. 126. 
the proposed Child Labor Amendment both of the former consequences must follow mediately or immediately. Since these involve rights and immunities so expensively acquired they should not be given up unless the closer adjustment of government to the needs of the governed makes it necessary. To surrender and destroy them where the existing powers are adequate would be folly approaching the abandonment of our constitutional scheme of government. The justification for the Child Labor Amendment lies in the desire to effect, through affirmative governmental action, the liberation of the child of tender years from "sweat-shop" conditions. With this humanitarian principle no right-minded person can disagree. There are many other aspects, however, to the enactment of a child labor amendment of any kind and the existing proposal in particular. Even if it is possible to procure a child labor amendment, no amendment which carries such widespread opposition as the one pending should be adopted. No proposal for national child labor control by constitutional amendment has escaped widespread opposition. Even though such legislation can be promulgated, when we are dealing with as enduring a standard as a constitutional provision it cannot be wise and wholesome if opposition will be so extensive as to bring disrespect for government. The measure which we are considering is one which, if it is unpopular, would be impossible to enforce without a large police force. Surely the repetition of the experience of the nation under an unpopular amendment, noble as the experiment might be, should not be sought. ${ }^{6}$ It is the purpose of this discussion to demonstrate that no such amendment is necessary or desirable.

6 "If this amendment should go into the Constitution it would go in because all good men, this committee no less than any other, abhor abuses of cbild labor. I tbink it is agreed by thinking men-and I believe the gentleman wbo just concluded his remarks will agree with me when I say that the Eighteenth Amendment came out of the Constitution not because the people of this country were any less in favor of temperance but because they resented the destruction of the fundamental law of our land by legislation being engrafted in it. I say to the gentleman wbo has just.concluded that we are not debating child labor or the evils of child labor. We are debating tbe protection of the Constitution of the United States..." Mr. James A. Simpson, Chairman of the Special Committee on the ratification of the Child Labor Amendment, (1936) 61 A. B.A. REP. at 180. The report of the Special Committee on Amendments and Legislation Relating to Child Labor of the American Bar Association, July, 1938, shows that on the referendum to the members of the association a vote of about five to one agaimst the outstanding proposal $(10,840$ to 2,743$)$. On the modified proposal known as the Vandenburg Amendment nearly half of those voting opposed the measure (Yes: 7,729; No: 5,777). A. B. A. Advance Prograni Includnig Coamarittee and Section Reports (1938) at 265.

The statements made in some of the debates in state legislatures on the proposed 
Within the individual state there nay be adequate power to control the employment of children. However, we are not here concerned with the states' power, for however comprehensive it may be, the piecemeal treatment by forty-nine jurisdictions within the continental limits, does not provide an adequate remedy for that unwholesome condition. In addition the limitations upon the states because of the national character of many industries within their borders, make uniformity even within an individual state impossible. We must then turn to the nation for a competent sovereign. The nation has only enumerated powers to deal even with common problems. An undesirable practice may be stifled, either by direct prohibition or by so burdening the conduct that its continuation is no longer attractive. The taxing power and the commerce power seem to measure the potential national control over child labor. We shall first deal with remedy through the national power to control interstate commerce. Both will be discussed under the assumption that no change is to be made in the Constitution.

THE COMMERCE POWER

Two decisions of the Supreme Court of the United States have precipitated the problem. As long as they remain, the sediment will never be wholly dissolved by any of the reagents now being advocated or administered. The cases can never be completely overruled under the present frame-work of our national order. The first of the cases to be considered here is Hammer v. Dagenhart. ${ }^{7}$ Basically the Court there held that Congress cannot regulate the wholly internal affairs of the states-matters purely local in character. The obvious reason why the significance of this case can never be removed from decisions of the Supreme Court is that ours is a federal form of government with two distinct types of sovereigns. Our subject is (child) labor. Labor deals with commerce and industry. Including the nicety of shading, these concepts-labor, commerce, and industry-include every economic activity. Necessarily some substantial part of that activity must, by its very intimacy with things that are inherently local as distinguished from national, remain within the powers exclusively reserved by the Constitution to the states. ${ }^{8}$ Even though the com-

ratification of the outstanding proposal as to the consequences of such an amendment are most alarming to those who believe in the efficacy of our scheme of government.

7 (1918) 247 U. S. 251.

8 "If centripetal forces are to be isolated to the exclusion of the forces that oppose and counteract them, there will be an end to our federal system." Mr. Justice Cardozo, concurring in A. L. A. Schechter Poultry Corp. v. United States (1935) 295 U. S. 495, 554. 
merce clause undergo the broadest possible interpretation, the national power will not include jurisdiction of important facts in the field. All of the commerce can never be entirely "weith foreign nations, and among the several States...." This must be true, or the commerce clause enables the Congress to destroy the states-and this no one contends. Wherever the line is drawn, diversity of jurisdiction arises, and efficient as well as effective enforcement of standards ends. ${ }^{10}$ This may not be the wisest statesmanship, but as the Court put it:

"It is not the province of the Court to consider the economic advantages or disadvantages of such a centralized system. It is sufficient to say that the Federal Constitution does not provide for it .... The efforts of the federal government must be made in a manner consistent with the authority granted by the Constitution." 11

To the extent of its regulatory power, within the scope of interstate commerce, Congress can establish uniform standards throughout the nation.

These standards of control may take the form of prohibition of the employment, or of an embargo on the products from the channels of interstate commerce. Licensing might be used to implement either or both. ${ }^{12}$ The difficulty with the first is that, even if the prohibitory power exists, the line soon merges into local action beyond the borders of national power. ${ }^{13}$ This makes engagement in business

0 U. S. Const., Art. I, § 8, cl. 3. Italics added.

10 "I find no authority in that grant [the commerce clause] for the regulation of wages and hours of labor in the intrastate transactions that make up the defendants' business. As to this feature of the case hittle can be added to the opinion of the court. There is a view of causation that would obliterate the distinction between what is national and what is local in the activities of commerce.... Activities local in their immediacy do not become interstate ... because of distant repercussions." Mr. Justice Cardozo concurring in the Schechter Case, supra note 8.

11 Ibid. at 549. This statement was made in answer to the claims of the government. "The Government also makes the point that efforts to enact state legislation establishing high labor standards have been impeded by the belief that unless similar action is taken generally, coinmerce will be diverted from the States adopting such standards, and that this fear of diversion has led to demands for federal legislation on the subject of wages and hours. The apparent implication is that the federal authority under the commerce clause should be deemed to extend to the establishment of mles to govern wages and hours in intrastate trade and industry generally throughout the country, thus overriding the authority of the States to deal with domestic problems arising from labor conditions in their internal commerce." Ibid. at 549.

12 Cf. S. 3072, 75th Cong., 2d Sess. (Nov. 16, 1937).

13 "What is near and what is distant may at times be uncertain... There is no penumbra of uncertainty obscuring judgment here. To find immediacy or directness bere is to find it almost everywhere." Mr. Justice Cardozo in the Schechter Case, supro note 8 , at 554 . 
a hazard, and enforcement litigious, expensive and uncertain. A large police force becomes necessary. When the industrial pump needs priming it seems unwise to put sand in the wheels by such frictioncausing methods.

At any event the nation has no probe long enough to cauterize the bottom of the infection. ${ }^{14}$ Here we are met with various alternatives. One calls for simple supplementation, that is, for the states to take up where the nation leaves off. In the first place this calls for a duplication of legislation and police force in each of the states and doubles the friction in the industrial machine. Secondly, where is the line at which one starts or the other ends? This promises to more than double the litigation at the border. ${ }^{15}$ The second is that either Congress, or, conversely, all the state legislatures, by several action, give up to the other, powers which could be exercised to the exclusion of the other sovereign. All methods are subject to the initial uncertainty that the asserted power may be unconstitutional. Eventually, of course, litigation would settle some of these difficulties. Only the voluntary surrender could give jurisdiction for similarity of treatment. If Congress gave up its powers, umiformity would be possible. But even though possible, there is the improbability of forty-nine identical statutes in the several jurisdictions within the continental limits. Even if this could be achieved there would be the deterrent to business through the obligation to account to many states. State limes no longer measure industrial enterprise. The probability that each of the states would uniformly give up enough of its constitutional reserved power soon enough to allow Congress to cover the whole field is too improbable to be practical even if constitutional. ${ }^{16}$

Greater sanitation in the control of the disease of child labor than has been heretofore practised is of course possible. Several part-way

14 "Although activities may be intrastate in character when separately considered, if they have such a close and substantial relation to interstate commerce that their control is essential or appropriate to protect that commerce from burdens and obstructions, Congress cannot be denied the power to exercise that control ... Undoubtedly the scope of this power inust be considered in the light of our dual system of government and may not be extended so as to embrace effects upon interstate commerce so indirect and remote that to embrace them, in view of our complex society, would effectually obliterate the distinction between what is national and what is local and create a completely centralized government... The question is necessarily one of degree." National Labor Relations Bd. v. Jones \& Laughlin Steel Corp. (1937) 301 U. S. 1, 37.

15 All of the states and Congress have now adopted a child labor law of some sort.

16 "Neither consent nor submission by the States can enlarge the powers of Congress; none can exist except those that are granted." Ashton v. Cameron County Water etc. Dist. (1936) 298 U. S. 513, 531. 
measures are available. Even though they be too clumsy and expensive to be attractive they should be noticed before going on to the discussion of the taxing power.

Our particular concern is, how far can the federal government enter the states? If there must be a line between what is local and what is national it would seem that to it the nation can press in, and beyond it the states may not go. While our inquiry concerns only the federal power the states' power cases aid in surveying the mutually exclusive areas. In fact, however, there are two lines, depending upon conditions, which mark state jurisdiction. It is the oversight of this which has caused confusion in interpreting the cases dealing with the boundary line. The second area is not, as often called, a penumbra, but an area as distinct as a solar corona. There are three areas, not two. Between each of these areas the shadows shift causing the penumbra cases. The inner circle is the commerce which is wholly, exclusively, and peculiarly local; the outer, by the same signs, national, and from which the states are wholly excluded. ${ }^{17}$ In the corona, however, either or both may enter. The importance of the distinction arises from the contention that Congress has discretion to surrender interstate commerce regulatory power. It is submitted that no decision of the Supreme Court justifies such a conclusion. The conclusion that the decisions recognize such a power in Congress means that a power taken from the states and vested exclusively in the Congress by the Constitution can, at the pleasure of Congress, be turned back to the states. As will be shown presently, no case has yet required such a decision under the commerce clause. Under an analogous relationship, however, the Court has found such a proposition purely specious. In 1917 a state statute was held to be an attempt to enter the exclusively federal field. No state legislation affecting substantive maritime law, said the Court, "is valid if it ... works material prejudice to the characteristic features of the general maritime law, or interferes with the proper harmony and uniformity of that law in its international and interstate relations." 18 Congress immediately attempted to provide such authority to the states. In Knickerbocker Ice Co. v. Stevart ${ }^{19}$ it was held that the attempt was unconstitutional as being a delegation of legislative powers to the states and a defeat of the Constitution in preserving the harmony and uniformity of

17 Wabash, St. Louis \& Pac. Ry. Co. v. Illinois (1886) 118 U.S. 557. Cf. J. D. Adams Co. v. Storen (1938) 58 Sup. Ct. 913.

18 Southern Pac. Co. v. Jensen (1917) 244 U. S. 205, 216.

19 (1920) 253 U. S. 149. 
maritime law. Again Congress sought to give the states jurisdiction in this federal field. The same principle was applied in Washington v. W. C. Dawson \& $\mathrm{Co} .{ }^{20}$ to invalidate the act of Congress. Congress was conceded power to legislate within the constitutional grant but was powerless to return a part of that power taken from the states for national purpose. ${ }^{21}$ The disability of Congress to divest itself of this granted power is further evidenced by the zealousness with which the Supreme Court guards departmentalization in Crovell v. Benson..$^{22}$ It is true that the national commerce power arises under the First Article while the provision as to admiralty jurisdiction arises under the Third. Both, however, are national powers defined by the Constitution and previously reposing in the states. Clearly the limits of national admiralty are not left to be fixed by the discretion of Congress but are reserved for the Court under the doctrine of judicial review. ${ }^{23}$

It is commerce among the several states which is committed to federal jurisdiction-interstate commerce. In the concededly controlling case of Cooley v. Board of Wardens two areas of such commerce were recognized in the following often repeated language: ${ }^{24}$

"Now the power to regulate commerce, embraces a vast field, containing not only many, but exceedingly various subjects, quite unlike in their nature; some imperatively demanding a single uniform rule, operating equally on the commerce of the United States in every port; and some, like the subject now in question, as imperatively demanding that diversity, which alone can meet the local necessities of navigation."

These two areas may be called local-interstate commerce and national-interstate commerce. Both sovereigns have jurisdiction in the former, but only the United States can regulate the latter. The jurisdiction of the states depends upon the factual nature of the transactions involved. The jurisdictional fact was reserved for the approval of the judiciary-Congress could not adjust the line against the fact so as to permit the states to enter the area of control exclusively granted to the nation to regulate national-interstate com-

20 (1924) 264 U.S. 219.

21 The amphibious cases present an interacting area similar to the commerce corona. Millers' Indemnity Underwriters v. Braud (1926) 270 U. S. 59 ; Alaska Packers Assn. v. Industrial Acc. Comm. (1928) 276 U. S. 467 ; Sultan Ry. etc. Co. v. Dept. of Labor etc. (1928) 277 U.S. 135.

22 (1932) 285 U. S. 22.

23 Cf. Marbury v. Madison, supra note 1.

24 (1851) 53 U.S. (12 How.) 299, 319. 
merce. In local-interstate commerce the states are not materially handicapped by the commerce clause ${ }^{25}$ in the absence of assumption of control by Congress. Congress is privileged to enter and oust the states. But as local-interstate commerce is one "imperatively demanding that diversity which alone can ineet the local necessities" 20 and Congress has the discretion, the working rule is to require a clear showing of the congressional purpose to occupy the field exclusively. ${ }^{27}$ A thing in motion takes some time and space after speed begins, to decrease until it comes to complete rest. Normally when the goods have come to complete rest the full power of the state attaches. ${ }^{28}$ This may be because all federal jurisdiction has ended ${ }^{20}$ or because the movement is within the zone of local-interstate commerce. Much of the jurisprudence has developed about the place where the line is drawn without in any way affecting the principle. The adjustment has been largely in the modification of the original-package doctrine. In Leisy v. Hardin ${ }^{30}$ the Court held that goods delivered in interstate commerce continued beyond state control while they remained in their original packages. ${ }^{31}$ The original-package doctrine is no longer (if it ever was) the test of national-interstate commerce. ${ }^{32}$ Original packages are evidence of interstate commerce but not the test. "In brief, the test of the original package is not an ultimate principle. It is an illustration of a primciple ... It marks a convenient boundary ..." 33 The consequence of modification of the original-package

25 Cf. Mayor etc. of Vidalia v. MeNeely (1927) 274 U. S. 676.

26 Cooley v. Board of Wardens, supra note 24.

27 "The power conferred upon the Congress is such that when exerted it excludes and supersedes state legislation in respect of the same matter. But Congress may so circumscribe its regulation as to leave a part of the subject open to state action. Allantic Coast Line v. Georgia, 234 U.S. 280, 290. Cf. Napier v. Atlantic Coast Lint, 272 U.S. 605. The purpose exclusively to regulate need not be specifically declared. New York Central $R$. Co. v. Winfield, 244 U.S. 147. But, ordinarily such intention will not be impled unless, when fairly interpreted, the federal measure is plainly inconsistent with state regulation of the same matter. Illinois Cent. R. Co. v. Public Utilities Comm'n, 245 U. S. 493, 510." Gilvary v. Cuyahoga Valley Ry. Co. (1934) 292 U. S. 57, 60.

28 Sonneborn B Brothers v. Cureton (1923) 262 U.S. 506.

29 Cf. Henneford v. Silas Mason Co. (1937) 300 U. S. 577.

30 (1890) 135 U.S. 100.

31 Cf. Sonneborn Brothers v. Cureton, supra note 28.

32 "The form of the packages in such circumstances is immaterial, whether they are original or broken." Baldwin v. Seelig, Inc. (1935) 294 U.S. 511, 527. "The interstate transaction ... ends upon delivery to the consignee." Whitfield v. Ohio (1936) 297 U.S. 431,439 . Use and enjoyment are subject to valid nondiscrimimatory regulation. Henneford v. Silas Mason Co., supra note 29.

33 Baldwin v. Seelig, Inc., supra note 32 , at 527 . Wearing traveling clothes is evidence that one is a traveler, just as the fact that one is covered with snow in a warm 
doctrine is to eliminate Clark Distilling Co. v. Western Md.Ry.Co., ${ }^{34}$ as a holding that Congress has discretion to return to the states powers vested in it by the Constitution. No modification of the Cooley Case is effected by the Clark Distilling Co. Case.$^{35}$ Congress merely made it clear that it had not entered the field of local-interstate commerce to the exclusion of the states. ${ }^{36}$ This seems to be expressed by the Court in Whitfield v. Ohio, where the Court said, the ${ }^{3 \tau}$

"statute simply permits the jurisdiction of the state to attach immediately upon delivery, whether the importation remain in the original package or not. In other words, the importation is relieved from the operation of any rule which recognizes a right of sale in the unbroken package witlout state interference-a riglit the exercise of which never has been regarded as a fundamental part of the interstate transaction, but only as an incident resulting therefrom."

That the Court was aware of the issue is shown by the statement: ${ }^{38}$

"If the power of Congress to remove the impediment to state control presented by the unbroken-package doctrine be hmited in any way (a question which we do not now find it necessary to consider), it is clear that the removal of that impediment in the case of prison-made goods must be upheld for reasons akin to those which moved this court to sustain the validity of the Wilson Act. Even without such action by Congress the unbroken-package doctrine, as applied to interstate commerce, has come to be regarded, generally at least, as more artificial than sound."

The cooperation of the nation by the statutes involved, merely removed any doubt as to the intention of Congress which might be raised by Bowman v. Chicago and N.W.Ry.Co. ${ }^{39}$ as to whether Congress had excluded the states from local-interstate commerce. ${ }^{40}$ It did not (and as for anything that has been held, could not) give jurisdiction to the states which would be non-existent without con-

room, if it is snowing outside, is evidence that he has just come indoors. Neither is proof of the Ultimate Fact.

34 (1917) 242 U.S. 311, arising under the Webb-Kenyon Act of 1913.

35 Contra: Ribble, National and State Cooperation Under the Commerce Clause (1937) 37 CoL. L. REv. 43.

36 If we use the analogy to the eye, of the pupil, the iris, and the sclera, the changing of the area by the modification of the original-package doctrine might be likened to the expansion and contraction of the pupil in darkness and light.

37 Supra note 32, at 439 .

$38 \mathrm{Ibid}$. at 440 .

30 (1888) 125 U.S. 465.

40 A inaterial difference in attitude toward the occupancy by Congress of the field of local-interstate commerce from that expressed in the Bowman Case is shown by the 
gressional action. The states' jurisdiction was not derived from a cession by Congress.

Affirmative action definitely cooperative in fact is shown, however, in the Ashurst-Sumners Act of $1935 .{ }^{41}$ Here something otherwise not within state power was contributed by the cooperative action of Congress. National-interstate commerce as any other arch must have rests for both ends. Exports must be received. Even though a state can control local production it probably cannot prevent exportation in interstate commerce. ${ }^{42}$ Certainly the state of destination cannot prevent their receipt. ${ }^{43}$ By the Hawes-Cooper Act, upheld in Whitfield v. Ohio ${ }^{44}$ Congress provided that after imported prison-made goods were delivered the laws of the state of destination might be applied non-discriminately. This was a gracious and encouraging gesture, but unnecessary. ${ }^{45}$ The Ashurst-Sumners Act, with certain exceptions, makes it unlawful knowingly to transport in interstate commerce goods made by convict labor into any state where the goods are intended to be received, processed, sold, or used in violation of its laws. A means of evasion of local law is thus withdrawn by the closing of the channels of interstate commerce. ${ }^{46}$ The power

following statement: "The case calls for the well-established principle that Congress may circumscribe its regulation and occupy a limited field, and that the intent to supersede the exercise by the State of its police power as to matters not covered by the federal legislation is not to be implied unless the latter fairly interpreted is in actual conflict with the state law." Townsend v. Yeomans (1937) 301 U.S. 441, 454.

41 (1935) 49 StaT. 494,49 U. S. C. SUPP. III (1937) § 62.

42 Cf. Sligh v. Kirkwood (1915) 237 U. S. 52, where peculiar police interests attached.

43 Rhodes v. Iowa (1898) 170 U.S. 412; Adams Express Co. v. Kentucky (1909) 214 U.S. 218. "What is ultimate is the principle that one state in its dealings with another may not place itself in a position of economic isolation." Baldwin v. Scelig, stipra note 32 .

44 Supra note 32.

45 Highland Farms Dairy v. Agnew (1937) 300 U.S. 608.

$46 \mathrm{~A}$ similar supplenenting cooperative action is shown by Congress in the Act of Augnst 16, 1937, 50 STAT. 653, 11 U.S.C. SUPP. III (1937) § 401, amending the Bankruptcy Act by adding Chapter 10 providimg for composition of indebtedness of the taxing agencies or instrumentalities therein described. It should be noted that here the Congress was acting within a specially granted (the bankruptcy) power. If any modification of power resulted in the composition it was the power of the states. The states are free to modify their governmental agencies' powers unless restricted by their own constitutions or by the requirement of Article 4, Section 4, a political not a judicial question. Cf. Highland Farms Dairy v. Agnew, supra note 45. Factually, however, there was no surrender of state powers but the plenary exercise of those powers by the equivalent of contract action. "... If there is any obstacle to its exercise in the case of 
of Congress to withdraw its highways from the purposes of boot-leggers is upheld in the following significant language:

"The pertinent point is that where the subject of commerce is one as to which the power of the State may constitutionally be exerted by restriction or prohibition in order to prevent harmful consequences, the Congress may, if it sees fit, put forth its power to regulate interstate commerce so as to prevent that commerce from being used to impede the carrying out of the state policy." 47

The litigious nature of this procedure is conspicuous in the expression "where the subject of commerce is one as to which the power of the state may constitutionally be exerted." This opens two questions, (1) the power of the state (with congressional supplementation), and (2) the power of Congress to close the channels independently of state action. The Kentucky Whip Case recognizes national toll-bridge powers at least as great as that which "may constitutionally be exerted by restriction or prohibition (by the states) in order to prevent harmful consequences." This raises the issue of the constitutional limits upon the states to restrict or to prohibit conduct involving child labor. While it is not the purpose of this paper to analyze in detail those limitations, it is proper to consider some pertinent references in that regard; they also have a direct bearing on the issues in the latter part of this paper. The basic issue involved in the Whitfield Case was the validity of the Ohio statute. The Court upheld the power of the state upon the following view: ${ }^{48}$

“... that free labor, properly compensated, cannot compete successfully with the enforced and unpaid or underpaid convict labor of the prison. A state basing its legislation upon that conception has the right and power, so far as the federal Constitution is concerned, by non-discriminatimg legislation, to preserve its policy from impairment or defeat, by any means appropriate to the end and not inconsistent with that instrument."

Two bases for validity for our purpose thus appear, (1) a sound general labor policy, and (2) problems peculiar to the child. If the

the districts organized under state law it lies in the right of the State to oppose the federal interference. The State steps in to remove this obstacle. The State acts in aid, and not in derogation, of its sovereign powers." United States v. Bekins (1938) 304 U.S. $27,54$.

47 Kentucky Whip, etc. Co. v. Illinois Central R. Co. (1937) 299 U.S. 334, 351. The distinction should be noted between the action of Congress here and that taken in the action held invalid in United States v. Constantine (1935) 296 U.S. 287.

${ }^{48}$ Supra note 32 , at 439 . 
state establishes a valid fair-labor standard, goods produced in violation of that standard are tainted as contraband, as an incident to preserving the policy from impairment or defeat, ${ }^{40}$ to the extent that their sale in the open market can be restricted or prohibited. In this sense the goods cease, for the purpose of the issue, to be legitimate articles of commercial intercourse. The limits on such restraint are measured by whether it can affirmatively be shown that the restraint or prohibition is a means reasonably appropriate to the enforcement of a basic public policy. If the employment of children is of itself of such importance to the problem of unemployment, fair-labor practices, and social and economic welfare, that it supplies the legislative jurisdictional fact for regulation, then the search need go no further. ${ }^{50}$ This point will be referred to later in connection with the second problem. The states, however, are not foreclosed by so tenuous a theory. The question depends upon the police power of the state. In Sturges etc. Co. v. Beauchamp ${ }^{51}$ the result depended upon the validity of a state statute which prohibited the employment in specified occupations of children under the age of sixteen years. The matter was dismissed with the statement that," "It cannot be doubted that the state was entitled to prohibit the employment of persons of tender years in dangerous occupations. ... The imposition of absolute requirements of this sort is a familiar exercise of the protective power of government." There is even a broader base for the regulatory power of the state over the liberty of contract:

"... the liberty safeguarded is liberty in a social organization which requires the protection of law against the evils which menace the health, safety, morals, and welfare of the whole people ....

"There is an additional and compelling consideration which recent economic experience has brought into a strong hight. The exploitation of a class of workers who are in an unequal position with respect to bargaining power and are thus relatively defenceless against the denial of a living wage is not only detrimental to their health and well being but casts a direct burden for their support upon the community .... The community is not bound to provide what is in effect a subsidy for unconscionable employers. The community may direct its law-making power to correct the abuse which springs from their selfish disregard of the public interest." 53

${ }^{19}$ Cf. United States v. Doremus (1919) 249 U.S. 86.

50 Cf. supra note 2 .

51 (1913) 231 U.S. 320.

52 Ibid. at 325.

53 West Coast Hotel Co. v. Parrish (1937) 300 U.S. 379, 391, 399. 
It is proper to comment on what has already become obviousthat the regulation of commerce, whether by the state or nation, is subject to the operation of limitations imposed by the Constitution. Both are subject to the control effected by the due process clauses. In addition the state is limited by the commerce clause, ${ }^{54}$ and the nation in turn is limited to interstate commerce, local-interstate and national-interstate, by the reservations of the Tenth Amendment. To the extent of the police power the states may regulate local commerce, or local-interstate commerce and under the Kentucky Whip Case Congress can supplement that regulation by toll-bridge methods on the highways among the states. With both classes of interstate commerce Congress undoubtedly enjoys a police power as great as that of the states over purely local commerce. To goods which are vicious as distinguished from harmless, Congress has power to padlock the national highways from interstate intercourse independently of state action. ${ }^{55}$ Several recent cases ${ }^{56}$ have been thought to overrule Hammer v. Dagenhart. ${ }^{57}$ This is unfounded. Clearly these cases have expanded the range of local-imterstate commerce, but this is a far cry from overruling the principle that local production unassociated in any material way with interstate commerce is not subject to federal control. True, these cases give to Congress a factually wider range of federal police power, and in the exercise of its control over interstate commerce the means employed by Congress may have the quality of police regulations, ${ }^{58}$ but the principle remains unchanged. If the construction I have placed on the Whitfield Case is sound, the extent of state power, independently of Congress, is much broader than is commonly supposed. But even with the combined sum of the powers of both sovereigns, even if complete regulation could be effected one way or another, the result, as previously pointed out above, is undesirable. It would be dilatory, litigious, and expensive.

54 Cf. S. D. Adams Mfg. Co. v. Storen, supra note 17.

55 Champion v. Ames (1903) 188 U.S. 321; Hipolite Egg Co. v. U.S. (1911) 220 U.S. 45 ; United States v. Hill (1919) 248 U.S. 420.

56 Virginian Ry. Co. v. System Federation No. 40 (1937) 300 U.S. 515, under the Railway Labor Act; National Labor Relations Bd. v. Jones \& Laughlin Steel Corp., supra note 14; National Labor Relations Bd. v. Friedman-Marks Clothing Co. (1937) 301 U.S. 58, and other cases under the National Labor Relations Act of 1935.

07 The recent Fair Labor Standards Act of 1938 hangs entirely on this theory of absorption and dove-tailing (PuB. L. No. 718, 75th Cong. 3d Sess. (June 25, 1928)). The jurisdiction of Congress, of course, extends as far as interstate commerce.

ss Kentucky Whip Case, supra note 47. 
This conclusion would point to amendment if no simple adequate control is possible..$^{59}$ It is the purpose of the following discussion to show that such a means is now available.

\section{TAXATION}

If the employment of children may be subjected to a national burden it can be made so unattractive that it will no longer be a troublesome infection in the body politic. Here we encounter what has been generally accepted as an impervious wall in the second of the two cases previously referred to, ${ }^{60}$ namely, Bailey $v$. Drexel Furniture $\mathrm{Co}^{61}{ }^{\mathbf{1}} \mathrm{I}$ purposely refrain from calling it the Child Labor Tax Case as is customary because in fact it was not a tax case at all. In the previous discussion we have seen that,

"In the Hammer case, the Court concluded that the Act of Congress there under consideration had as its aim the placing of local production under federal control .... In other words, although the power over interstate transportation was to regulate, that could only be accomplished by prohibiting the use of the facilities of interstate commerce to effect the evil intended ... And in a few months after the Hammer case, the Court in United States $v$. Hill, ... emphatically reiterated the doctrine..."

In Hammer v. Dagenhart Congress was found to have trespassed upon the field of commerce control reserved exclusively to the states and that, by whatever name the misconduct was called, was not a proper exercise of the national regulatory power over interstate commerce. It was an unconstitutional attempt to regulate local commerce. A similar attempt was before the Court in the Drexel Furniture Case. The Court there said: ${ }^{63}$

"Although Congress does not invalidate the contract of employment or expressly declare that the employment within the mentioned ages is illegal, it does exhibit its intent practically to achieve the latter result by adopting the criteria of wrongdoing and imposing its principal consequence on those who transgress its standard.

"The case before us can not be distinguished from that of Hammer v. Dagenhart ... Congress there enacted a law to prohibit transportation in

59 For the uncertainty consequent on amendment in general, see Fraenkel, What Can be Done About the Constitution and the Supreme Court? (1937) 37 Cor. L. REv. 212.

60 Cf. supra note 7.

61 (1922) 259 U.S. 20.

62 Kentucky Whip Case, supra note 47, at 350 .

63 Supra note 61, at 38,37 . 
interstate commerce of goods made at a factory in which there was employment of children within the same ages and for the same number of hours a day and days in a week as are penahzed by the act in this case. This court held the law in that case to be void. It said:

" In our view the necessary effect of this act is, by means of a prohibition against the movement in interstate commerce of ordinary commercial commodities, to regulate the hours of labor of children in factories and mines within the States, a purely state authority.'

"In the case at the bar, Congress in the name of a tax which on the face of the act is a penalty seeks to do the same thing, and the effort must be equally futile.

"The analogy of the Dagenhart Case is clear. The congressional power over interstate commerce is, within its proper scope, just as complete and unlimited as the congressional power to tax, and the legislative motive in its exercise is just as free from judicial suspicion and inquiry. Yet when Congress threatened to stop interstate commerce in ordinary and necessary commodities, unobjectionable as subjects of transportation, and to deny the same to the people of a State in order to coerce them into compliance with Congress's regulation of state concerns, the court said this was not in fact regulation of interstate commerce, but rather that of State concerns and was invalid. So lere the so-called tax is a penalty to coerce people of a State to act as Congress wishes them to act in respect of a matter completely the business of the state government under the Federal Constitution ...

"In the light of these features of the act, a court must be blind not to see that the so-called tax is imposed to stop the employment of children within the age limits prescribed. Its prohibitory and regulatory effect and purpose are palpable. All others can see and understand this. How can we properly shut our minds to it?"

Again by whatever name it was called ${ }^{64}$ it was not a (tax) revenue measure.

Our question then becomes, if the action in the Drexel Furniture Case was not a revenue measure, can the taxing poreer of Congress be used to control child labor? Assuming for the time being that there is regulatory power in Congress over child labor in inter-state transactions, since no such power exists over local commerce, the validity of the measure must depend solely on the revenue power if it is to have the desired result. This makes the choice of action more narrow and is the controlling element overlooked by Congress in the statute before the Court in the Drexel Furniture Case. The difference between a tax and a penalty is sometimes difficult to

64 Calling these acts to regulate interstate commerce or a "cliild labor tax law" did not make them such. Neither did the entitling of the Webb-Kenyon Act cause the action of Congress to be a restoration to the states of powers transferred exclusively to Congress by the Constitution. Cf. supra note 35 . 
define and yet the consequences of the distinction in the required method of their collection are often important. Where the sovereign enacting the law has power to impose both tax and penalty, the difference between revenue production and mere regulation may be immaterial, but not so when one sovereigu can impose a tax only, and the power of regulation rests on another. Taxes are occasionally imposed in the discretion of the legislature on proper subjects with the primary motive of obtaiming revenue from them and with the mcidental motive of discouraging them by making their continuation onerous. They do not lose their character as taxes because of the incidental motive. But there comes a time in the extension of the penalizing features of the so-called tax when it loses its character as such and becomes a mere penalty with the characteristics of regulation and punishment. It is against the error of universal assumption that a tax making onerous employment of children is impossible under the Drexel Furniture Case that this discussion is directed. The way is pointed out by the Court in the Drexel Furniture Case. The Court said an act can" 65 not be declared invalid just because another motive than taxation, not shown on the face of the act, umight have contributed to its passage." If there is a proper subject matter, an excise graduated as to rates upon factual differences therein may be validly imposed. If we can find these, a present, simple, effective, and commonly understood remedy may be applied with nominal cost of administration and without substantial alarm or burden to commerce. ${ }^{68}$ The social infection and the clog on the labor market can be simultaneously and simply corrected. This statement is so tremendous in its significance that it seems alarming. I have felt this, but the solution seems so clearcut and obvious $I$ have the temerity to draw the conclusion. Too many unsupported personal views are common which seem to involve merely the virtues of individual theories of political philosophy independent of constitutional limitation. ${ }^{67} \mathrm{I}$ pray indulgence in following rather closely the language of the Supreme Court in recent opinions because it forms the mold by which the shape and dimensions of any new legislative policy must find form and sufficiency.

To solve our problem we must examine the general scope of the taxing power, the propriety of its application to the subject matter in hand, and the validity of classification therein. More definitely,

65 Supra note 61, at 43.

66 Cf. Sturges v. Beauchamp, supra note 51 .

67 Cf. Landis, Administrative Policies and the Courts (1938) 47 Yare L. J. 519. 
but as yet without exclusive precision, may employment be the subject matter of a federal excise tax (in the nature of an income tax or otherwise), in which there is included a classification based upon age?

"That the authority conferred upon Congress by $\S 8$ of Article 1 'to lay and collect taxes, duties, imposts and excises' is exhaustive and embraces every conceivable power of taxation has never been questioned, or, if it has, has been so often authoritatively declared as to render it necessary only to state the doctrine. And it has also never been questioned from the foundation, without stopping presently to determme under which of the separate headings the power was properly to be classed, that there was authority given, as the part was included in the whole, to lay and collect income taxes. Again, it has never, moreover, been questioned that the conceded complete and all-embracing taxing power was subject, so far as they were respectively applicable, to limitations resulting from the requirements of Art. 1, $\S 8$, cl. 1, that 'all duties, imposts and excises shall be uniform throughout the United States,' and to the limitations of Art. 1, § 2, cl. 3, that 'direct taxes shall be apportioned among the several States' and of Art. I, §9, cl. 4, that 'no capitation, or other direct, tax sliall be laid, unless in proportion to the census or enumeration herembefore directed to be taken.' In fact the two great subdivisions embracing the complete and perfect delegation of the power to tax and the two correlated limitations as to such power were thus aptly stated ...: 'In the matter of taxation, the Constitution recognizes the two great classes of direct and indirect taxes, and lays down two rules by which their imposition must be governed, namely: The rule of apportionment as to direct taxes, and the rule of uniformity as to duties, imposts and excises.' It is to be observed, however, as long ago pointed out in Veazie Bank v. Fenno,... that the requirement of apportionment as to one of the great classes and of uniformity as to the otlier class were not so much a limitation upon the complete and all embracing authority to tax, but in their essence were simply regulations concerning the mode in whicl the plenary power was to be exerted." as

Federal action not being subject to an "equal protection" clause must be at least as extensive as that of the states.

"The States, in the exercise of their taxing power, as with respect to the exertion of other powers, are subject to the requirements of the due process and the equal protection clauses of the Fourteenth Amendment, but that Amendment imposes no iron rule of equality, prohibiting the flexibility and variety that are appropriate to schemes of taxation. The State may tax real and personal property in a different manner. It may grant exemptions. The State is not bimited to ad valorem taxation. It may impose different specific taxes upon different trades and professions and may vary the rates of excise

BS Brushaber v. Union Pac. R. R. Co. (1916) 240 U. S. 1, 12. 
upon various products. In levying such taxes, the State is not required to resort to close distinctions or to maintain a precise, scientific uniformity with reference to composition, use, or value. To hold otherwise would be to subject the essential taxing power of the State to an intolerable supervision, hostile to the basic principles of our Government and wholly beyond the protection which the general clause of the Fourteenth Amendment was intended to assure." 69

These expressions seem sufficient treatment of the general taxing power. Both deal with excises, or at least an income and an excise tax.

It should be borne in mind as we progress that the government is not confined to the taxing of vocations or activities which might be prohibited, nor does it matter that the privilege, if it be such, is created by state law. ${ }^{70}$ The power to classify for taxation is broader than the power to classify for regulation or prohibition. ${ }^{11}$

That a classification may be made for the purpose of different rates within the subject matter of a valid excise is a principle of such common application that it would seem to be sufficient to recite it. However, it may be better to observe some of the judicial expressions in that regard. In the Ohio Oil Co. Case the Court recognizes as settled the power to graduate rates where the classification within the subject matter is based on some ground of difference having a fair and substantial relation to the object of the legislation so that all persons similarly circumstanced shall be treated alike, and in doing so the taxing authority has "a large discretion." A classification is not made invalid by reason of a failure to describe the classifications scientifically. The power is even more broadly stated in Stebbins v. Riley. ${ }^{73}$ In the Brushaber Case the Court dismisses the claim of invalidity based upon a classification of rates: ${ }^{74}$

69 Ohio Oil Co. v. Conway (1930) 281 U.S. 146, 159. The following cases were then cited: "Bell's Gap Railroad Co. v. Pennsylvania, 134 U.S. 232, 237; Magount v. Illinois Trust \& Savings Bank, 170 U.S. 283, 293; Southwestern Oil Company v. Texas, 217 U.S. 114, 121; Brown-Forman Company v. Kentucky, 217 U.S. 563, 573; Sinnday Lake Iron Company v. Wakefield, 247 U.S. 350, 353; Heisler v. Thomas Colliery Company, 260 U.S. 245, 255; Oliver Iron Mining Company v. Lord, 262 U.S. 172, 179; Stebbins v. Riley, 268 U.S. 137, 142."

70 Stebbins v. Riley (1925) 268 U.S. 137.

71 Cf. Standard Oil Co. v. Lincoln (1927) 275 U. S. 504, with Williams v. Standard Oil Co. (1929) 278 U. S. 235.

72 Supra note 69.

73 Supra note 70. This is an inheritance-estate tax case.

74 Supra note 68 , at 25 . 
"... the proposition disregards the fact that in the very early history of the Government a progressive tax was imposed by Congress and that such authority was exerted in some if not all of the various income taxes enacted prior to 1894 ... And over and above all this the contention but disregards the further fact that its absolute want of foundation was plainly pointed out in Knowlton v. Moore, ... and the right to urge it was necessarily foreclosed by the rule in that case made."

Cooley says, "License or occupation fees or taxes may be graduated, where the classification for that purpose is reasonable." 75

751 Coolex, The LAW of TaXation (4th ed. 1924) \$354, et seq.: "They may be graduated according to the population of the city or town where the business is done, the locality in which the business is conducted, whether the dealer taxed is a wholesale or retail dealer, the amount of the gross receipts, the value of the stock employed in the business, or the assessed valuation of the stock or capital employed. So a tax on carriers who drive wagons, drays, etc., is lawfully apportioned according to the number of vehicles used by them respectively, and such apportionment accords with the uniformity rule.

"Peddlers' taxes may be graduated according to the means of locomotion. Classification of hotels according to the number of rooms they contain is proper for the purpose of determining the amount of inspection fees. The license fee on boarding houses may be graduated according to whether the meals are cooked by the proprietor or meunbers of his family or by others. Classifying bakers, as to the amount of their hicense fee, according to the baking surface operated, is not unreasonable. Grading a municipal license fee on theatres according to the price asked for the highest price seats, instead of according to revenue, is proper. Dairymen may be taxed according to the number of cows kept. Requiring barber shops to pay a license of five dollars a year, and two dollars additional for each chair where more than two chairs are used, is proper. Auctionneers' licenses may be graduated according to the kind of property sold. It is proper classification to require a higher license tax from shows other than circuses, given in tents, than is required for a regular theatre building. Uniformity 'on the same class of subjects' is satisfied by classifying oil separate for inspection fees and subclassification as to quantity, with a higher fee for smaller lots. A difference in license rates between those selling oil from tank wagons or barrels transported through the streets, making a lower rate for those who sell in a different way, is valid, since the difference in the manner of distribution is a reasonable classification, the former way imposing a greater burden on the streets.

"\$355 ... If a State, for example, were to decide to levy an occupation tax upon one of the learned professions, it might decide to lay the same tax upon each niember, or it might discriminate so that the tax should be proportioned to the professional incoune. Either course would be admissible, provided the rule were made general, though the latter may be the more equitable. This requirement as to uniformity does not necessitate the graduation of an occupation tax in proportion to the busmess transacted, and small traders or dealers may be taxed the same amount or rate as large dealers or traders. For instance, an occupation tax on gas companies, the amount being the same without regard to the amount of business done by each, does not violate the rule as to uniformity." Cf. im accord: Chicago, Burhington \& Quincy R. R. Co. v. Iowa (1876) 94 U.S. 155, 164 ; Dow v. Beidelman (1888) 125 U.S. 680, 691 ; Maine v. Grand Trunk Ry. Co. (1891) 142 U.S. 217, 228; Clark v. Titusville (1902) 184 U.S. 329; Spreckels Sugar Refining Co.v.McClain (1904) 192 U.S. 397; Metropolis Theatre Co.v. Chicago (1913) 
In New York Rapid Transit Corp. v. City of New York the Court expands the concept of reasonable discretion in classification for tax purposes. ${ }^{76}$

"Although the wide discretion as to classification retained by a legislature, often results in narrow distinctions, these distinctions, if reasonably related to the object of the legislation, are sufficient to justify the classification ... Indeed, it has long been the law under the Fourteenth Amendment that a 'distinction in legislation is not arbitrary, if any state of facts reasonably can be conceived that would sustain it' .... 'The rule of equality permits many practical inequalities' .... 'What satisfies this equality has not been and probably never can be precisely defined'...

"The power to make distinctions exists with full vigor in the field of taxation, where 'no iron rule' of equality has even been enforced upon the states ... A state may exercise a wide discretion in selecting the subjects of taxation ... 'particularly as respects occupation taxes...""

The "object" of the legislation as used in the rule "is the object of the taxing provisions, i.e., the raising of the money" for a public purpose. The absence of some special relation between the taxpayer and the use to be made of the proceeds is not material, for "a tax is not an assessment of benefits." Such a relationship is "something the Constitution does not require. There need be no relation between the class of taxpayers and the purpose of the appropriation." The authorities "support the view that the 'object' is the revenue to be raised by the acts." The validity of the object and public purpose are assumed ${ }^{77}$ for the purpose of this discussion.

In our examination so far, the authorities only approach our issue but do not solve it. We must now seek more specifically whether employment of child labor is a reasonable legislative classification for revenue purposes.

The answer does not rest on conceptions of subject, measure and rate of tax. ${ }^{78}$ Much broader considerations touching internal policy of police may sustain the exaction.

228 U.S. 61; Chesapeake \& O. Ry. Co. v. Conley (1913) 230 U.S. 513, 522; Pacific American Fisheries v. Alaska (1925) 269 U.S. 269; Hope Natural Gas Co. v. Hall (1927) 274 U.S. 284; State Board of Tax Commissioners v. Jackson (1931) 283 U.S. 527.

76 (1938) 303 U.S. $573,578$.

77 Cf. Social Security Cases: Carmichael v. Southern Coal \& Coke Co. (1937) 301 U.S. 495; Steward Machine Co. v. Davis (1937) 301 U.S. 548; Helvering v. Davis (Davis Case) (1937) 301 U.S. 619, 672.

78 In entering upon the inquiry of whether employment is a proper classification for taxation the development in the field of workmen's compensation should be noted. 
"In the exercise of its police power the state may forbid, as inimical to the public welfare, the prosecution of a particular type of business, or regulate a business in such manner as to abate evils deemed to arise from its pursuit. Whatever a state may forbid or regulate it may permit upon condition that a fee be paid in return for the privilege, and such a fee may be exacted to discourage the prosecution of a business or to adjust competitive or economic inequalities. Taxation may be made the implement of the exercise of the state's police power; and proper and reasonable discrimination between classes to promote fair competitive conditions and to equalize economic advantages is therefore lawful." " 79

Statutes allowing employees a remedy against employers for the negligence of a fellow servant and depriving the employers of the defense of contributory negligence are not unconstitutional because limited to railroads. Missouri P. Ry. Co. v. Mackey (1888) 127 U.S. 205. And such statutes are not rendered unconstitutional because not applicable to employees engaged in constructing new and unopened railroads. Minnesota Iron Co. v. Kline (1905) 199 U. S. 593, or because limited to railroads corporately owned. Aluminum Co. v. Ramsey (1911) 222 U.S. 251. They may include employees not subject to the hazards resulting peculiarly from the operation of a railroad (Louisville \& N. R. R. Co. v. Melton (1910) 218 U. S. 36) or confined to those whose occupation exposed them to hazards incident to the operation of trains. Chicago, I. \& L. Ry. Co. v. Hackett (1913) $228 \mathrm{U}$.S. 559. In the absence of any particular showing of erroneous classification, the evident purpose of a workmen's compensation act to classify the various occupations according to the respective hazard of each is sufficient answer to any contention that it improperly distributes the burdens among the several industries. Mountain Timber Co. v. Washington (1917) 243 U.S. 219. The exemption of farm laborers, domestic servants, etc., does not render an act unconstitutional. New York C.R.R. Co. v. White (1917) 243 U.S. 188. A workmen's compensation act denying nonconformers employing five or more persons of the defense of contributory negligence, assumed risk, and the negligence of fellow servants in negligence suits, does not deny equal protection of the laws because the act is not applicable to employers of less than five. Jeffrey Mfg. Co. v. Blagg (1915) 235 U.S. 571. Equal protection is not denied an employer by a workmen's compensation act which allows him the common law defenses of assumption of risk, contributory negligence, and negligence of fellow servants only wben he has accepted the act and the employee has not, while it withdraws them if employer and employee both, or employer alone, have rejected it. Hawkins v. Bleakly (1917) 243 U.S. 210. The discrimination resulting between employees engaged in the same kind of work, where one employer exercises his option to come under the workmen's compensation act and another does not, is not inconsistent with the equal protection clause. Middleton v. Texas Power \& Liglit Co. (1919) 249 U.S. 152. There is a sufficient distinction between coal mining and other hazardous employments to justify a state in applying its workmen's compensation system to the one (coal mining) compulsorily, while leaving it permissive, or not applying it at all, to others. Lower Vein Coal Co. v. Industrial Board (1921) 255 U. S. 144. A workmen's compensation act taking away an existing right of action for wrongful death of an employee not only as against the employer but as against any third person by whose negligence the death may have been caused is not a denial of equal protection. Northern P. Ry. Co. v. Meese (1916) 239 U. S. 614. And an act imposing a liability on the wrongdoer to indemnify the insurer where an award has been paid to the state as required in the particular instance does not deny equal protection of the law. Staten I. Rapid Transit Ry. Co. v. Phoenix Indemnity Co. (1930) 281 U.S. 98.

70 Great Atlantic \& Pacific Tea Co. v. Grosjean (1937) 301 U. S. 412, 425. Italics added. 
Where there is a menace to public welfare the state is at liberty to regulate the matter directly or to resort to taxation..$^{80}$ To this statement the reply will be suggested that regulatory power in the state does not establish national regulatory power. However, we are not seeking national regulatory power as such but only a proper basis for classification for taxation. We shall return to this point later. Let us now examine the subject matter of the classification -employment. It seems to matter little whether the revenue burden be called a tax on income, ${ }^{81}$ an excise, or an impost, for no problem of a direct tax is involved. At any event the burden herein contemplated is a revenue measure. ${ }^{82}$

As excises have commonly been associated with property, and occasional judicial expressions have emphasized privilege, the assumption has been drawn that these concepts limit the taxing power ${ }^{83}$ From this it was concluded that employment, as a privilege and natural right not associated with property, cannot be made the subject matter of an excise tax. The Social Security Cases $^{84}$ wholly refute such a claim of invalidity. Even though earlier taxes were so limited the forms then accepted would not now measure legislative choice. But they were not so limited, and included from colonial times excises upon employers and employments in husbandry, business, and personal service. Natural rights, so-called, are as much subject to taxation as rights of less importance.

"An excise is not limited to vocations or activities that may be prohibited altogether. It is not limited to those that are the outcome of a franchise. It extends to vocations or activities pursued as of common right. What the individual does in the operation of a business is amenable to taxation just as much as what he owns, at all events if the classification is not tyrannical or arbitrary. 'Business is as legitimate an object of the taxing power as property' .... Indeed, ownership itself, as we had occasion to point out the other day, is only a bundle of rights and privileges invested with a single name ... 'A state is at hiberty, if it pleases, to tax them all collectively, or to separate the faggots and lay the cliarge distributively' ... Em-

80 Ibid.

81 Hale v. State Board (1937) 302 U.S. 95.

82 Social Security Cases, all supra note 77.

83 "... We are of the opinion that it is not broad enough to include every occupation which one may follow, in the exercise of a natural right ... They are performed in the exercise of a natural right and are not in any sense rights or privileges conferred by law." O'Keefe v. Somerville (1906) 190 Mass. 110, 76 N. E. 457. Cf. Howes Brothers Co. v. Massachusetts Unemployment Compensation Comm. (Mass. 1936) 5 N. E. (2d) 720, cert.den., (1937) 300 U.S. 657. Cf. Maguire, Taxing the Exercise of Natural Rights, HaRvard Legai EsSays (1934) 273.

84 Supra note 77. 
ployment is a business relation, if not itself a business. It is a relation without which business could seldom be carried on effectively. The power to tax the activities and relations that constitute a calling considered as a unit is the power to tax any of them. The whole includes the parts." 85

\section{From this the Court concludes in the Carmichael Case: ${ }^{86}$}

"Taxes, which are but the means of distributing the burden of the cost of government, are commonly levied on property or its use, but they may likewise be laid on the exercise of personal rights and privileges. As has been pointed out by the opinion in the Chas. C. Stevard Machine Co. case, such levies, including taxes on the exercise of the right to employ or to be employed, were known in England and the Colonies before the adoption of the Constitution, and must be taken to be embraced within the wide range of choice of subjects of taxation, which was an attribute of the sovereign power of the states at the time of the adoption of the Constitution .... The character of the exemptions suggests simply that the state has chosen, as the subject of its tax, those who employ labor in the processes of industrial production and distribution."

It is not a matter of conclusion from the above, but of narration, that employment is a proper subject of taxation. In pursuing the national power to classify further we find that "The subject matter of taxation open to the power of Congress is as comprehensive as that open to the power of the states, though the method of apportionment may at times be different." 87 In describing the freedom of selection of subjects of taxation and the granting of exemptions by a state, the Carmichael Case points out the absence of any rigid rule of equality. ${ }^{88}$ The presumption of constitutionality is emphasized by the statement that "Only by faithful adherence to this guiding principle of judicial review of legislation is it possible to preserve to the legislative branch its rightful independence and its ability to

85 Steward Machine Co. v. Davis, supra note 77, at 580.

86 Supra note 77 , at 508,512 . Italics added.

87 Steward Machine Co. v. Davis, supra note 77, at 581.

88 "It is inherent in the exercise of the power to tax that a state be free to select the subjects of taxation and to grant exemptions. Neither due process nor equal protection imposes upon a state any rigid rule of equality of taxation.... This Court has repeatedly beld that inequahties which result from a singling out of one particular class for taxation or exemption, infringe no constitutional limitation...

"Like considerations govern exemptions from the operation of a tax imposed on the members of a class. A legislature is not bound to tax every member of a class or none. It may make distinctions of degree having a rational basis, and when subjected to judicial scrutiny they must be presumed to rest on that basis if there is any conceivable state of facts wbich would support it." Supra note 77, at 509. 
function." 89 It recognizes the scope of exemption, of purpose, and of application of benefits for the purpose of classification, as being as broad as the freedom of selection of subjects of taxation; and that there is no reciprocal inter-dependence of relationship between the burden or taxpayer and the benefit or purpose. We must now move to the next stage-may there be a classification of employment based upon age?

It has been pointed out that while forms of excises commonly understood at the time of the adoption of the Constitution do not measure legislative discretion, available selection is at least as broad now as then. Authorities then and since recognize age as a proper classification. In the Steward Machine Co. Case the Court said: ${ }^{20}$

"This is to throw over the argument that historically an excise is a tax upon the enjoyment of commodities. But the attempted distinction, whatever may be thought of its validity, is inapplicable to a statute of Virginia passed in 1780. There.a tax of three pounds, six shillings, and eiglit pence was paid for every male tithable above the age of twenty-one years (with stated exceptions), and a like tax for 'every white servant whatsoever, except apprentices under the age of twenty-one years.' ... Our colonial forbears knew more about ways of taxing than some of their descendants seem to be willing to concede."

The Social Security Act ${ }^{91}$ itself contains several classifications based upon age. These include sections 302 (b) 2, 402, 404, 410, 1004, 1011 , and 1107. A point specifically in issue in the Davis Case was the validity of such classification. It has previously been pointed out that a purpose for which an appropriation can be made within the meaning of the general welfare clause may also furnish a valid classification for taxation. Both are reflected here. The tax was levied upon employment under Title VIII to provide funds (to put it most strongly) for the maintenance of persons over sixty-five years of age under Title II. The wisdom of the classification, said the Court, "is not for us to say. The answer to such inquiries must come from Congress . . ." "The classifications and exemptions directed by the statute now in controversy have support in considerations of policy and practical convenience that cannot be con-

89 Ibid. at 510.

90 Steward Machine Co. v. Davis, supra note 77 , at 580.

81 (1935) 49 STAT. $620 ; 42$ U. S. C. SUPP. III (1937) § 302 et seq.

82 Helvering v. Davis, supra note 77, at 644. 
demned as arbitrary." 93 The Act includes in its classifications ${ }^{94}$ provisions for dependent children under the age of sixteen years; for the health ${ }^{95}$ of children; for the protection and care of homeless ${ }^{98}$ children; and excerpts from Title IX, "service performed by a child under the age of twenty-one in the employ of his father or mother." These classifications all seem to have been held by the Social Security Cases within the discretion of Congress for excise purposes. Some of them were directly in issue. The differences peculiarly affecting morals, health, employment, and the general welfare, would seem no less important in those without equality of bargaining power because of incapacity due to extreme youth, than where it is due to old age.

We need not pause here, however. The Court pointed out in the Grosjean $\mathrm{Case}^{97}$ that a classification which is valid for police power purposes is sufficient for tax purposes. This was repeated in New York Rapid Transit Corp. v. City of New York ${ }^{98}$ where the revenue measure merely adopted the classification previously established by the New York Public Service Law. The public welfare is the overtone throughout the Social Security Cases as the basis for classification. In the Carmichael Case it is said: ${ }^{99}$

"This Court has long and consistently recognized that the public purposes of a state, for which it may raise funds by taxation, embrace expenditures for its general welfare ... The existence of local conditions which, because of their nature and extent, are of concern to the public as a whole, the modes of advancing tle public interest by correcting them or avoiding their consequences, are peculiarly within the knowledge of the legislature, and to it, and not to the courts, is committed the duty and responsibility of making choice of the possible methods."

In West Coast Hotel Co. v. Parrish, where the classification involved a membership of full contractual capacity, it was said: ${ }^{100}$

"The legislature of the State was clearly entitled to consider the situation of women in employment, the fact that they are in the class receiving the least pay, that their bargaiming power is relatively weak, and that they

93 Steward Machine Co. v. Davis, stupra note 77, at 584.

94 (1935) 49 StaT. 620, \$401; 42 U.S. C. Stup. III (1937) \$601.

95 Ibid. §501; 42 U.S. C. SUPP. III (1937) §701.

86 Ibid. §521; 42 U.S. C. SUPP. III (1937) §721.

07 Supra note 79.

98 Supra note 76.

99 Carmichael v. Southern Coal \& Coke Co., supra note 77, at 514.

100 (1937) 300 U.S. 379. 
are the ready victims of those who would take advantage of their necessitous circumstances. The legislature was entitled to adopt measures to reduce the evils of the 'sweating system,' the exploiting of workers at wages so low as to be insufficient to meet the bare cost of living, thus making their very helplessness the occasion of a most injurious competition. The legislature had the right to consider that its minimum wage requirements would be an important aid in carrying out its policy of protection. The adoption of similar requirements by many States evidences a deepseated conviction both as to the presence of the evil and as to the means adapted to check it. Legislative response to that conviction cannot be regarded as arbitrary or capricious and that is all we have to decide. Even if the wisdom of the policy be regarded as debatable and its effects uncertain, still the legislature is entitled to its judgment."

Of our children it may be said as appropriately as of their mothers"Their relative need in the presence of the evil, no less than the existence of the evil itself, is a matter for the legislative judgment." "101 Widespread legislative classification and public opinion are given great weight in the Parrish Case quoted above. In the Whitfield Case it is also given great weight: ${ }^{102}$

"The view of the State of Ohio that the sale of convict-made goods in competition with the products of free labor is an evil, finds ample support in fact and in the similar legislation of a preponderant number of the other states. Acts of Congress relating to the subject also recognize the evil ... And the sale to the public in competition with private enterprise of goods made by convicts imprisoned under federal law is forbidden ... All such legislation, state and federal, proceeds upon the view that free labor, properly compensated, cannot compete successfully with the enforced and unpaid or underpaid convict labor of the prison. A state basing its legislation upon that conception has the right and power, so far as the federal Constitution is concerned, by non-discriminating legislation, to preserve its policy from impairment or defeat, by any means appropriate to the end and not inconsistent with that instrument."

On the importance of the incapacity of the state to master the problem even locally it is said in the Davis Case: ${ }^{103}$ "The problem is plainly national in area and dimensions. Moreover, laws of the separate states cannot deal with it effectively. Congress, at least, had a basis for that belief .... Only a power that is national can serve the interests of all." If widespread recognition gives ground for valid police regulation, and police regulation in turn for classifica-

101 Ibid. at 400.

102 Supra note 32 , at 439.

103 Steward Machine Co. v. Davis, supra note 77, at 644. 
tion in taxation, universal police regulation of child labor should justify a classification based upon tender age for taxation. ${ }^{104}$ Every state in the Union and the United States ${ }^{105}$ now inpose some sort of regulation or prohibition on the employment of persons less than a specified age. These regulations are valid.

"It cannot be doubted that the State was entitled to prohibit the employment of persons of tender years in dangerous occupations... It is urged that the plaintiff in error was not permitted to defend upon the ground that it acted in good faith relying upon the representation made by Beauchamp that he was over sixteen. It is said that, being over fourteen, he at least had attained the age at which he should have been treated as responsible for his statements. But, as it was competent for the State in securing the safety of the young to prohibit such employment altogether, it could select means appropriate to make its prohibition effective and could compel employers, at their peril, to ascertain whether those they employed were in fact under the age specified. The imposition of absolute requirements of this sort is a familiar exercise of the protective power of government." 106

\section{Age is a valid classification within employment for the purpose of excise taxation. ${ }^{107}$}

104 The following combination of grounds for classification is expressed in the Carmichael Case. "Reasons for the selections, if desired, readily suggest themselves. Where the public interest is served one business may be left untaxed and another taxed, in order to promote the one... The legislature may withliold the burden of the tax in order to foster what it conceives to be a beneficient enterprise. This Court las often sustained the exemption of charitable institutions,... and exemption for the encouragement of agriculture ... Similarily, the legislature is free to aid a depressed industry such as shipping. The exemption of business operating for less than twenty weeks in the year may rest upon similar reasons, or upon the desire to encourage seasonal or unstable industries." Carmichael v. Southern Coal \& Coke Co., supra note 77, at 512.

${ }_{105}$ Fair Labor Standards Act of 1938 (Pub. L. No. 718, 75th Cong. 3d Sess. (June $25,1938)$ ).

106 Sturges \& Burn Mfg. Co. v. Beauchamp (1913) 231 U. S. 320, 325, under a statute which prohibited the employment of children under the age of sixteen years. Cf. In re Sharp (1908) 15 Idaho 120, 96 Pac. 563, (1909) 18 L. R.A. (N.S.) 886; People v. Ewer (1894) 141 N. Y. 129, 36 N. E. 4, 25 L. R. A. 794, 38 Am. St. Rep. 788; State v. Shorey (1906) 48 Ore. 396, 86 Pac. 881 (1910) 24 L. R. A. (N.S.) 1121; Mill v. Brown (1907) 31 Utah 473, 88 Pac. 609, 120 Am. St. Rep. 935.

107 While the following statement was made in the Carmichael Case, supra note 77, at 510 , in regard to a classification based on the number of employees, it is pertinent to a classification based on the number of years: "Distinctions in degree, stated in terms of differences in number, have often been the target of attack, see Booth v. Indiana, 237 U.S. 391. It is argued here, and it was ruled by the court below, that there can be no reason for a distinction, for purposes of taxation, between those who have only seven einployees and those who bave eight. Yet this is the type of distinction which the law is often called upon to make. It is only a difference in numbers which marks the 
Though a valid excise tax can be laid on employment of children, say, for example, below the age of sixteen years, if its application would be unduly burdensome, either because of the irritation and inconvenience to employers or the expense of administration, the result would not be most happy. Neither is inescapable. The language of the Court in the Carmichael Case points the way. ${ }^{108}$ "There is a basis, on the grounds of administrative convenience and expense, for adopting a classification which would permit the use of records, kept by the taxpayer and open to the tax gatherer, as an aid to the administration ..." If there is in existence a revenue measure on the subject of employment, already held valid as to classification and public purpose, with an effective machinery for enforcement now in operation, it would seem to be a simple matter to raise in that classification a subdivision of employees less than sixteen years of age. With the exception of the latter, all are now in existence. Title VIII of the Social Security Act, which was held valid in Helvering $v$. Davis, lays an excise tax on employers. The tax on the employer is to be paid "with respect to having individuals in his employ." ${ }^{109}$ This is laid on every employer in addition to all other taxes. The excise tax is not applicable to certain types of employment, such as agricultural labor, domestic service, service for the national or state governments, and service performed by persons who have attained the age of sixty-five years. Two fundamental aspects of public policy are embraced in the last classification: firstly, by classifying employees over sixty-five as carrying no tax burden through their employment, to promote their employment in the public welfare; and, secondly, by providing old age benefits for those who are necessitous and unemployed. These were both in issue in the Davis Case. By the same token, a progressive rate may be made where the purpose is to stifle rather than promote the employment of persons at the other end of the scale. ${ }^{110}$ Two classes

moment when day ends and night begins, when the disabilities of infancy terminate and the status of legal competency is assumed. It separates large incomes which are taxed from the smaller ones which are exempt, as it marks here the difference between the proprietors of larger businesses who are taxed and the proprietors of smaller businesses who are not...

"It would hardly be contended that the state, in order to tax pay rolls, is bound to assume the administrative cost and burden of taxing all employers having a single employee." Italics added.

108 Supra note 77 , at 520 . Italics added.

109 (1935) 49 STAT. 620, at $637, \$ 804 ; 42$ U. S. C. Supr. III (1937) $\$ 1004$.

110 "Where the public interest is served one business may be left untaxed and another taxed, in order to promote the one, American Sugar Refining Co. v. Loutisiana, 
and rates are now applied on classifications of employment based on age. A third can be added on the same basis without materially increasing the burdens of industry or the cost of administration. ${ }^{111}$ This class would be children of sixteen years of age or less.

We must now consider further two issues which have been carried through the second part of the discussion. They both turn upon the burden of the tax and are mutually self-serving. Firstly, can the burden be made sufficiently great to discourage employment of children, and secondly, would it be a tax or a mere pretext as a tax measure? From the strenuous, rough road which we have been climbing, encouragement may be obtained from these issues through their self-serving relationship in cooperative action; the purpose and result of the excise tax, however, remain in question. The higher the operating cost as a consequence of the tax, the greater the discouragement to the use of cliild labor; yet the higher the burden or rate the greater the income to the government and the probability that the measure will be held an exertion of the taxing power. There is an underlying issue, however, and that is whether the Constitution limits the amount to which Congress can raise the rates of a tax. The taxing power, like the other great substantive powers of Congress, is subject to the due process clause of the Fifth Amendment and somewhere the imposition of a tax burden will reach a ceiling. There is sufficient head-room under it, however, for a prohibitive tax. In Magnano v. Hamilton ${ }^{112}$ the Court had before it a tax burden stifling in weight which had been imposed for the purpose of regulation. The Court said:

"That the tax is for a public purpose is equally clear, since that requirement has regard to the use which is to be made of the revenue derived from the tax, and not to any ulterior motive or purpose which may have influenced the legislature in passing the act. And a tax designed to be expended for a public purpose does not cease to be one levied for that purpose because

supra; Heisler v. Thomas Colliery Co., supra; Aero Transit Co. v. Georgia Public Service Commin, supra, or to restrict or suppress the other, Magnano Company v. Hamilton, 292 U.S. 40; Fox v. Standard Oil Co., supra; Quong Wing v. Kirkendall, supra; Singer Sewing Machine Co. v. Brickell, 233 U.S. 304; Alaska Fish Co. v. Smith, supra, 48; Great Atlartic \& Pacific Tea Co. v. Grosjean, supra." Carmichael v. Southern Coal \& Coke Co., supra note 77, at 512.

111. Three classes based on age were held valid in Breedlove v. Suttles (1937) 301 U.S. 277 ; minors, majors, and aged persons, for tax purposes.

112 (1934) 292 U.S. 40. 
it has the effect of imposing a burden upon one class of business enterprises in such a way as to benefit another class .... Except in rare and special instances, the due process of law clause contained in the Fifth Amendment is not a limitation upon the taxing power conferred upon Congress by the Constitution .... Collateral purposes or motives of a legislature in levying a tax of a kind within the reach of its lawful power are matters beyond the scope of judicial inquiry ... Nor may a tax ... be judicially stricken down under the due process clause simply because its enforcement may or will result in restricting or even destroying particular occupations or businesses."

Where the language of the act indicates a revenue purpose and there is nothing more than the premise "that the amount of the tax is so excessive that it will bring about the destruction of appellants' business, a premise which, standing alone, this Court heretofore has umformly rejected as furnishing no juridical ground for striking down a taxing act, ..." the statute will not be held invalid. "Those who enter upon a business take that risk." 113

Several recent cases indicate that a hazard of a non-revenue classification is practically non-existent. ${ }^{114}$ The slightest grounds are sufficient to mark the measure as an exertion of the taxing power

$113 \mathrm{Ibid}$. at 43.

114 In addition to the Magnano Case, supra note 112, the following cases are most assuring: Nigro v. United States (1928) 276 U.S.332; Sonzinsky v. United States (1937) 300 U.S. 506; and the Social Security Cases (the Steward Machine Co. Case in particular) all supra note 77. But ef. United States v. Constantine (1935) 296 U.S. 287. In the Nigro Case at page 352 the Court said: "Four inembers of the Court dissented in the Doremus case, because of opinion that the court below had correctly held the Act of Congress, in so far as it embraced the inatters complained of, to be beyond its constitutional power, and that the statute, in \$2 [(1914) 38 STAT. 785; 26 U.S.C. (1934) \$1044] was a mere pretext as a tax measure, and was in fact an attempt by Congress to exercise the police power reserved to the States and to regulate and restrict the sale and distribution of dangerous and noxious narcotic drugs. Since that time, this Court has held that Congress, by merely calling an Act a taxing act, cannot make it a legitimate exercise of taxing power under $\$ 8$ of Article 1 of the Federal Constitution, if in fact the words of the act show clearly its real purpose is otherwise. Child Labor Tax Case, 259 U. S. 20, 38. By the Revenue Act of 1918, the Anti-Narcotic Act was amended so as to increase the taxes under $\$ 1$, making an occupation tax for a producer of narcotic drugs $\$ 24$ a year, for a wholesale dealer, $\$ 12$, for a retail dealer, $\$ 6.00$, and for a physician administering the narcotics, $\$ 3.00$. The amendment also imposes an excise tax of one cent an ounce on the sale of the drug. Thus the income from the tax for the Government becoines substantial. Under the Narcotic Act, as now amended, the tax amounts to about one million dollars a year, and since the annendment in 1919 it has benefited the Treasury to the extent of nearly nine million dollars. If there was doubt as to the character of this Act-that it is not, as alleged, a subterfuge-it has been removed by the change whereby what was a nominal tax before was made a substantial one. It is certainly a taxing act now as we held in the Alston case." 
and not a regulatory measure. ${ }^{115}$ In the Sonzinsky Case $^{116}$ the validity of the National Firearms Act ${ }^{117}$ was attacked on the ground that it was not a true tax, but a penalty imposed for the purpose of suppressing traffic, the local regulation of which was reserved to the states because not granted to the national government. This position was mistaken. It was said that the cumulative effect on the distribution of a limited class of firearms, of relatively small value, by the successive imposition of different taxes, one on the business of the manufacturer, and another on that of the dealer, and a third on the transfer to the buyer, was prohibitive in effect and disclosed unmistakably the legislative purpose to regulate rather than to tax. The Court summarily dismissed the contention saying: ${ }^{118}$

"Full effect may be given to the license tax standing alone, even though all other provisions are invalid....

"The case is not one where the statute contains regulatory provisions related to a purported tax in such a way as has enabled this Court to say in other cases that the latter is a penalty resorted to as a means of enforcing the regulations ... Nor is the subject of the tax described or treated as

115 Where a tax does not violate any constitutional limitation it may not be restrained judicially because of the results which may arise from its application. (Tax of 10 cents per pound on artificially-colored oleomargarine, McCray v. United States (1904) 195 U.S. 27.) If the taxing statute shows on its face that its purpose is not that of raising revenue but the regulation of activities not within the scope of federal authority, its enforcement may be unrestrained. (Tax upon the net mcome of any person employing child labor, held, not an act imposing a tax under this clause and unconstitutional as an attempt to regulate state matters-Child Labor Tax Case (1922) 259 U.S. 20. See also United States v. Jin Fuey Moy (1916) 241 U.S. 394; Hill v. Wallace (1922) 259 U.S. 44; Linder v. United States (1925) 268 U.S. 5; Trusler v. Crooks (1926) 269 U.S. 475; Nigro v. United States, supra note 114; Casey v. United States (1928) 276 U.S. 413; United States v. Constantine, supro note 47. United States v. Butler (1936) 297 U.S. 1.) But where the tax bears a reasonable relation to a power conferred upon the federal government by the Constitution, the fact that Congress may have been equally or incidentally impelled by the motive of regulation will not invalidate it (fifty-cent tax on steamship companies for each immigrant brought into the country-Head Money Cases (1884) 112 U. S. 580. See also Veazie Bank v. Fenno (1869) 75 U. S. (8 Wall.) 533; J. W. Hampton, Jr., \& Co. v. United States (1928) 276 U.S. 394) even though it may affect the conduct of a business which is subject to regulation by the state police power, e.g., opium dealers required to register and pay taxUnited States v. Doremus (1919) 249 U.S. 86.

Congress under the taxing power may tax intoxicating liquors, notwithstanding their production is prohibited; and the fact that it does so for a moral end as well as to raise revenue is not a constitutional objection. United States v. Yuginovich (1921) 256 U.S. 450 .

116 Supra note 114.

117 (1934) 48 STAT. 1236; 26 U.S. C. (1934) \$\$1132-1132q.

118 Sonzinsky v. United States, supra note 114, at 512. 
criminal by the taxing statute ... Here $\S 2$ contains no regulation other than the mere registration provisions, which are obviously supportable as in aid of a revenue purpose. On its face it is only a taxing measure, and we are asked to say that the tax, by virtue of its deterrent effect on the activities taxed, operates as a regulation which is beyond the congressional power.

"Every tax is in some measure regulatory. To some extent it interposes an economic impediment to the activity taxed as compared with others not taxed. But a tax is not any the less a tax because it has a regulatory effect, ... and it has long been established that an Act of Congress which on its face purports to be an exercise of the taxing power is not any the less so because the tax is burdensome or tends to restrict or suppress the thing taxed...

"Inquiry into the hidden motives which may move Congress to exercise a power constitutionally conferred upon it is beyond the competency of courts.... They will not undertake, by collateral inquiry as to the measure of the regulatory effect of a tax, to ascribe to Congress an attempt, under the guise of taxation, to exercise another power denied by the Federal Constitution."

In the Nigro Case the question of whether the measure produced income to government was thought to be of importance. The National Firearms Act produced only a nominal return. Of this the Court in Sonzinsky v. United States, said: ${ }^{110}$

"Here the annual tax of $\$ 200$ is productive of some revenue. We are not free to speculate as to the motives which moved Congress to impose it, or as to the extent to which it may operate to restrict the activities taxed. As it is not attended by an offensive regulation, and since it operates as a tax, it is within the national taxing power."

The only remaining doubt would seem to be whether the herein proposed statutory amendment is subject to the above expression as "an offensive regulation" or as a trespass upon the reserved power of the states. Both of these are answered in the negative by the Social Security Cases. ${ }^{120}$

119 Supra note 114, at 514. The following cases were then cited: "Alston v. United States, 274 U.S. 289, 294; Nigro v. United States, supra, 332, 353; Hampton \& Co. v. United States, 276 U.S. 394, 411, 413."

120 Supra note 77. "It is one thing to impose a tax dependent upon the conduct of taxpayers, or of the state in which they live, where the conduct to be stimulated or discouraged is unrelated to the fiscal need subserved by the tax in its normal operation, or to any other end legitimately national.... It is quite another thing to say that a tax will be abated upon the doing of an act that will satisfy the fiscal need, the tax and the alternative being approximate equivalents. In such circumstances, if in no others, inducement or persuasion does not go beyond the bounds of power." Steward Machine Co. v. Davis, supra note 77, at 591. 
The Act to be amended is a revenue measure. The proposed amendment does not change its nature. The amendment to Title VIII would simply need to provide for an additional excise on employers of persons of sixteen years of age and less. The exemptions already provided meet the objections that have arisen in regard to any supervision of children in industry. The rate can be made as high as desired. It should be noted that if the present form of the statute is followed, namely, that of a percentage of wages, the element of confiscation, whatever its merit elsewhere, ${ }^{121}$ has no application here. The tax will not absorb the wages. It is an excise on employment measured by wages. If a greater burden be desired there is no objection to a different measure. Thus the value of the product, which has a clear relation to the subject-matter, could with equal validity be substituted for or added to the measure of wages. The burden need be no greater than whatever will make the employment of children, as compared with adults, unprofitable. It often happens that supervision of ouly one party to an unwholesome relation leaves invitation to the other to persist in the practice. More complete effectiveness of the deterrent purpose would also be achieved by raising the present special income tax upon the employees of the same class. No additional burden, except the increased tax, is involved in administration or to busmess. The operating machinery and practices are already fully established and generally understood and accepted.

No child labor amendment is necessary or desirable.

James Barclay Smith.

SCHOOL OF LAW,

UNTVESTTY OF KANSAS. 